\title{
PEMBUATAN INSTRUMEN SOAL INOVATIF MENGGUNAKAN APLIKASI HOT POTATOES BAGI GURU SDN SUKARAPIH 01 DAN 02 KABUPATEN BEKASI
}

\author{
Endaryono $^{1)}$, Rifki Ristiawan'), Nurfidah Dwitiyanti ${ }^{3)}$ \\ 1,2,3 Informatika, Fakultas Teknik dan Ilmu Komputer, \\ Universitas Indraprasta PGRI
}

\begin{abstract}
Abstrak
Informasi dan teknologi yang berkembang pesat berpengaruh terhadap proses pembelajaran di sekolah dasar. Siswa sekolah dasar cenderung lebih tertarik dengan penggunaan media pembelajaran yang bersifat permainan (games). Hal menjadi tantangan bagi guru untuk menciptakan permainan dengan memasukan materi ajar yang disesuaikan sehingga siswa termotivasi untuk mencari jawaban dan memperoleh pelajaran dari permainan tersebut. Sekolah Dasar negeri (SDN) Sukarapih 01 Bekasi dan SDN Sukarapih 02 Bekasi adalah sekolah dasar yang berada di Kabupaten Bekasi, Jawa Barat dan belum memanfaatkan metode pengajaran kontemporer dengan memanfaatkan teknologi. Kegiatan ABDIMAS ini bertujuan memberikan informasi dan referensi media pembelajaran yang dapat diterapkan di sekolah dasar, dalam hal ini penerapan aplikasi hot potatoes untuk membuat instrumen soal yang bersifat inovatif dan menarik minat siswa. Dalam pelaksanaan kegiatan, dilakukan pengenalan, pelatihan dan penerapan aplikasi hot potatoes untuk membuat instrumen soal bagi guru. Hasil yang diperoleh dari pelatihan ini cukup berdampak positif, pihak mitra sangat antusias mengikuti pelatihan, aktif dalam mengikuti materi pelatihan dan aktif bertanya saat pengoperasian aplikasi hot potatoes. Mereka menyatakan kepuasannya terhadap pelatihan yang telah dilaksanakan.
\end{abstract}

Kata kunci: pelatihan, permainan, media pembelajaran, hot potatoes, guru

\begin{abstract}
Information and technology that are growing rapidly affect the learning process in elementary school. The students of elementary school tend to be more interested in the use of game learning media. It becomes a challenge for the teacher to create a game by including customized teaching material so that students are motivated to find answers and learn from the game. SDN Sukarapih 01 dan 02 Bekasi are located in Kabupaten Bekasi, West Java and have not utilized contemporary teaching methods by utilizing technology. The ABDIMAS activity aims to provide learning media information and references that can be applied in elementary schools, in this case the application of hot potatoes applications to create question instruments that are innovative and attract students' interest. In the implementation of the activity, an introduction, training and application of hot potatoes were conducted to make a question instrument for the teacher. The results obtained from this training were quite positive, the partners were very enthusiastic in participating in the training, were active in participating in the training material and actively asked when operating the hot potatoes application. They expressed satisfaction with the training that had been carried out.
\end{abstract}

Keywords: training, games, learning media, hot potatoes, teachers

Correspondence author: Endaryono, endaryono@unindra.ac.id, Jakarta, Indonesia

This work is licensed under a CC-BY-NC 


\section{PENDAHULUAN}

Perkembangan informasi dan teknologi berkembang pesat. Hal ini berpengaruh terhadap proses pembelajaran, termasuk di tingkat sekolah dasar. Cara penyampaian materi dalam proses kegiatan belajar mengajar dan penggunaan media pembelajaran harus disesuaikan.

Siswa cenderung tertarik dengan penggunaan media pembelajaran yang bersifat permainan (games). Hal ini adalah peluang dan tantangan bagi guru untuk menciptakan media pembelajaran yang bersifat permainan sehingga siswa termotivasi dan merasa senang. Kenyataannya beberapa sekolah belum memanfaatkan teknologi dan metode terkini dalam pembelajaran. Guru belum memanfaatkan teknologi untuk tujuan pembelajaran.

Dilihat dari segi perkembangan teknologi, Seels \& Glasgow (dalam Ismail, 2007) membagi ke dalam dua kategori, yaitu pilihan media tradisional dan pilihan media teknologi mutakhir. Dalam media teknologi mutakhir terdapat media berbasis mikroprosesor salah satu contohnya adalah permainan komputer (Arsyad, 2012). Permainan pembelajaran atau game edukasi merupakan media yang cukup populer dan sedang banyak dikembangkan untuk mendukung proses pembelajaran di dalam kelas. Game edukasi bertujuan memancing minat belajar anak sambil bermain. Henry (2010) menyatakan game edukasi bertujuan memancing minat anak sambil belajar. Oleh karena itu, diperlukan adanya sebuah media berupa game edukasi yang mampu memberi efek menarik dan menyenangkan bagi siswa dalam proses pembelajarannya.

Hot Potatoes adalah suatu tool untuk membuat bank soal. Program Hot Potatoes terdiri atas enam program yang dapat digunakan untuk membuat materi pengajaran secara interaktif berbasis web. Software ini dibuat oleh Universitas Victoria di Kanada. Hot Potatoes dapat digunakan secara bebas oleh institusi pendidikan. Program ini dapat diperoleh melalui homepage di http://www.halfbakedsoftware.com atau melalui alamat http://hotpot.uvic.ca versi yang akan digunakan untuk pelatihan ini adalah Versi 6.3.0.5.

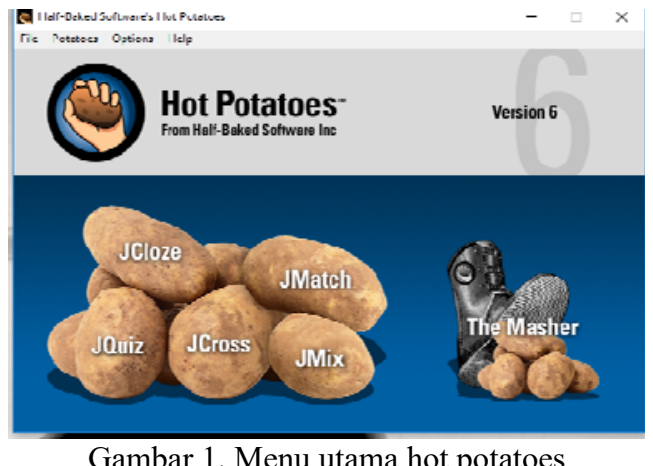

Dengan menerapkan hot potatoes dalam pembelajaran atau lebih spesiiknya dalam latihan pengerjaan soal, siswa akan lebih termotivasi untuk mengerjakan soal secara drill dan mencari menumbuhkan minat baca dan belajar siswa. Dalam game yang dihasilkan dari aplikasi hot potatoes ini, siswa akan barmain dengan beberapa pilihan permainan, mulai dari mengerjakan soal dalam bentuk teka-teki silang, menjodohkan, mengisi isian ompong dan lainnya dalam bentuk interaktif maupun dalam bentuk cetak.

SDN Sukarapih 01 dan Sukarapih 02 Kabupaten Bekasi memerlukan suatu pelatihan pemanfaatan teknologi untuk media pembelajaran. Untuk hal tersebut 
dilakukan kegiatan Program Kegiatan Pengabdian kepada masyarakat untuk memberikan informasi dan referensi media pembelajaran yang dapat diterapkan di sekolah dasar, dalam hal ini adalah penerapan aplikasi hot potatoes untuk membuat instrumen soal yang bersifat inovatif dan menarik minat siswa. Kami melakukan pelatihan pengenalan dan penerapan hot potatoes untuk membuat instrumen soal yang bersifat inovatif bagi guru SDN Sukarapih 01 dan Sukarapih 02 Kabupaten Bekasi.

\section{METODE PELAKSANAAN}

Kegiatan pengabdian kepada masyarakat (ABDIMAS) dilaksanakan pada bulan September - Desember 2018 atau selama 4 bulan. Pelatihan dilaksanakan bersama Guru SDN Sukarapih 01 dan 02 Kabupaten Bekasi. Tempat pelaksanaan meminjam ruang aula SMAN 1 Tambelang Kab. Bekasi, Desa Sukarapih, Kecamatan Tambelang Bekasi. Jarak pelaksanaan pengabdian kepada masyarakat dengan kampus Unindra gedung A adalah sekitar $150 \mathrm{KM}$.

Metode yang digunakan dalam pelaksanaan kegiatan ini adalah :

1. Metode ceramah

Penjelasan oleh narasumber tentang pengenalan dan penggunaan aplikasi hot potatoes.

2. Metode praktik

Dilakukan kegiatan pelatihan secara langsung bagi guru-guru untuk dapat membuat soal menggunakan aplikasi hot potatoes yang dikreasikan semenarik mungkin.

Langkah-langkah yang dilakukan dalam pelaksanaan dalam kegiatan pengabdian kepada masyarakat dapat dijelaskan pada diagram alur program yang tersaji pada Gambar 2

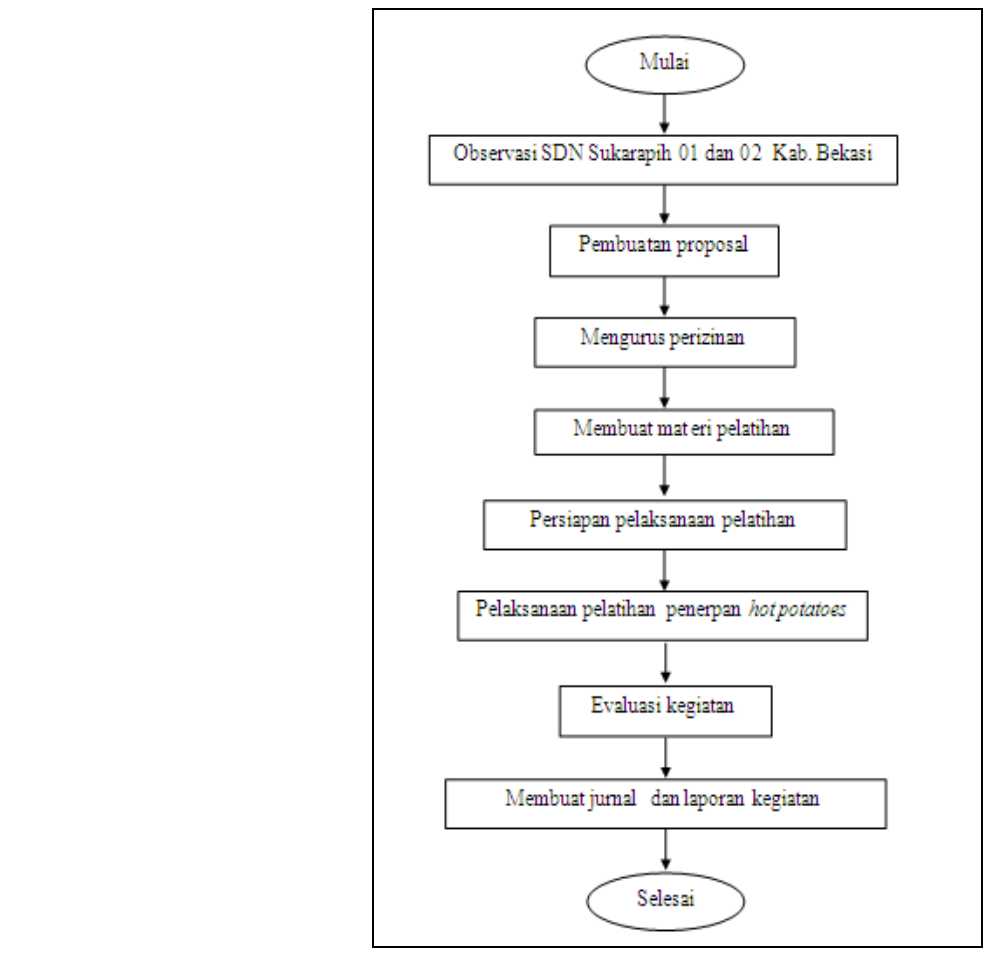

Gambar 2. Diagram alur program kegiatan pengabdian kepada masyarakat pelatihan penggunaan hot potatoes. 
Kegiatan ini dimulai dengan melakukan observasi ke lokasi SDN Sukarapih 01 dan 02 Kabupaten Bekasi. Lokasi berada di Desa Sukarapih Kecamatan Tambelang Kabupaten Bekasi. Dari observasi diketahui bahwa perlu adanya pelatihan pemanfaatan media pembelajaran dalam bentuk aplikasi yang dapat diterapkan dalam pembelajaran dengan tujuan untuk dapat memotivasi siswa dalam belajar.

Setelah observasi, tim Abdimas membuat proposal kegiatan pengabdian kepada masyarakat dengan tema pelatihan penggunaan aplikasi hot potatoes. Kegiatan selanjutnya, tim Abdimas mengurus beberapa perijinan untuk pelaksanaan pengabdian kepada masyarakat pada SDN Sukarapih 01 dan 02 Kabupaten Bekasi.

Langkah selanjutnya, tim Abdimas membuat dan menyiapkan materi pelatihan penggunaan aplikasi hot potatoes dan pembuatan instrumen soal dengan menggunakan hot potatoes. Materi ini nantinya akan disampaikan kepada guru-guru SDN Sukarapih 01 dan 02 Kabupaten Bekasi dengan mengadakan pelatihan dan dilanjutkan dengan praktik langsung dalam pembuatan instrumen soal menggunakan aplikasi hot potatoes.

Setelah melakukan pelatihan, tim abdimas melakukan evaluasi. Evaluasi ini merupakan respon dari peserta terhadap pelatihan yang diberikan. Evaluasi ini dilakukan untuk mengukur tingkat keberhasilan pelatihan penggunaan aplikasi hot potatoes yang telah dilakukan.

Tahap akhir dari kegiatan pengabdian kepada masyarakat adalah membuat laporan pertanggungjawaban pelaksanaan program. Selanjutnya tim membuat jurnal hasil dari pengabdian kepada masyarakat.

\section{HASIL DAN PEMBAHASAN}

Program kegiatan pengabdian kepada masyarakat dengan judul "Pelatihan Penerapan Aplikasi Hot Potatoes dalam Pembuatan Instrumen Soal Inovatif bagi Guru SDN Sukarapih 01 dan $02 \mathrm{Kab}$. Bekasi" telah dilaksanakan dalam kurun waktu 4 bulan (September-Desember 2018) mulai dari tahapan perencanaan, pelaksanaan hingga penulisan laporan.

Pelaksanaan pelatihan untuk guru SDN Sukarapih 01 dan 02 dilaksanakan di SMAN 1 Tambelang yang beralamatkan di Jalan Bulak Sepat Indah 01 Desa Sukarapih Kecamatan Tambelang Kabupaten Bekasi. Jarak SMAN 1 Tambelang dengan kampus Unindra kurang lebih sejauh $150 \mathrm{Km}$.

Tahap-tahap dalam kegiatan abdimas ini diawali dengan persiapan, pengurusan perijinan, sosialisasi, pelaksanaan, penutupan dan pembuatan laporan.

Tahap persiapan dengan melakukan rapat koordinasi awal untuk menentukan tema dan hal apa yang akan dilakukan selama program abdimas berlangsung. Selain itu, menentukan tempat yang akan digunakan untuk berlangsungnya abdimas.

Pengurusan perijinan dilakukan untuk memperoleh surat mitra, yaitu dengan SDN Sukarapih 01 dan Sukarapih 02. Surat mitra ini yang kemudian akan dimasukkan ke dalam proposal kegiatan. Proposal tersebut diajukan ke LPPM Unindra.

Sosialisasi di sekolah SDN Sukarapih 01 dan Sukarapih 02 dilaksanakan berbarengan yaitu pada tanggal 29 September 2018. Kegiatan sosialisasi di hadiri oleh guru, serta karyawan SDN Sukarapih 01 dan Sukarapih 02. Maksud dan tujuan dari sosialisasi ini adalah untuk memperkenalkan program pengabdian kepada masyarakat dari Unindra. Selain itu, tim abdimas beserta guru dan karyawan SDN Sukarapih 01 dan 02 menentukan waktu yang tepat untuk pelaksanaan pelatihan penggunaan hot potatoes 


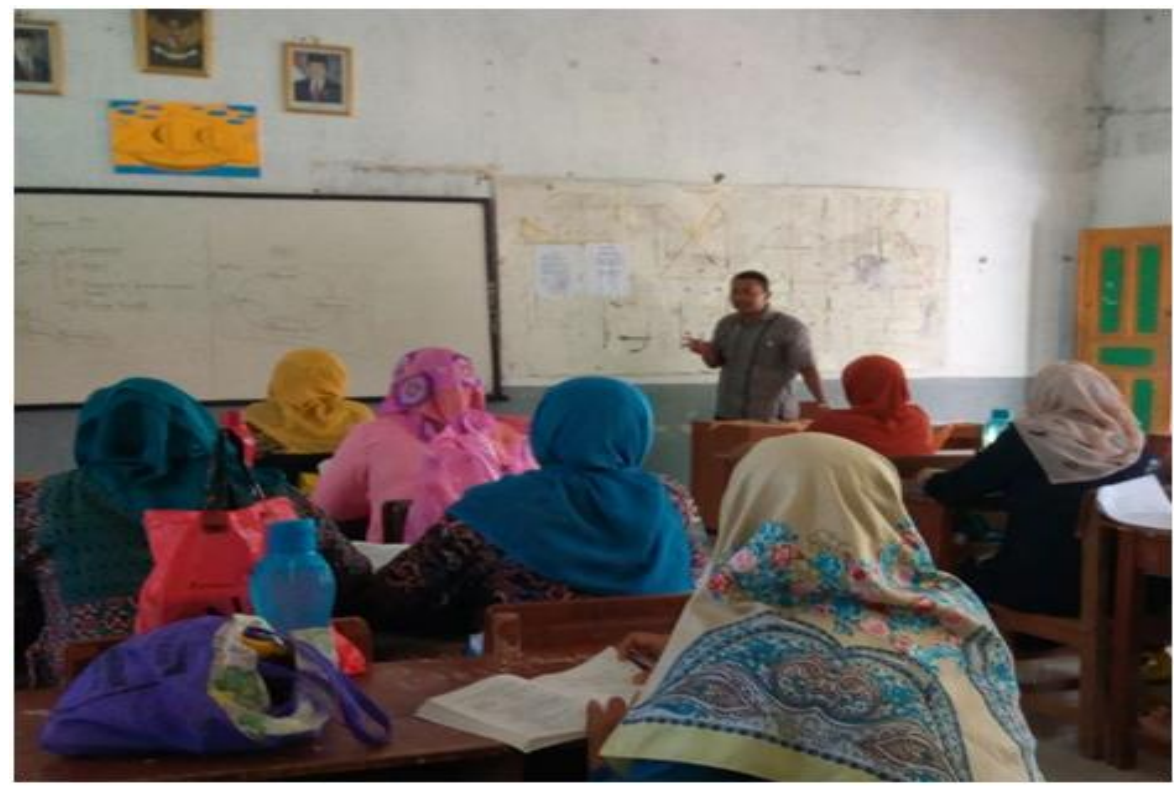

Gambar 3. Acara sosialisasi pelatihan hot potatoes.

Pelatihan kegiatan hot potatoes dilaksanakan pada hari Minggu, 29 Oktober 2018. Pelatihan dilaksanakan di ruang kelas SMAN 1 Tambelang yang tidak jauh dari SDN Sukarapih 01 dan 02. Pemilihan tempat pelaksanaan ini didasari dari kapasitas ruang kelas dan fasilitas sekolah seperti proyektor, katersediaan aliran listrik di kelas dan lainlain.

Waktu pelaksanaan pelatihan dimulai pukul 09.00 WIB sampai dengan 15.00 WIB. Karena kegiatan dilaksanakan di ruang kelas SMAN 1 Tambelang, maka masingmasing peserta sebelumnya telah diminta membawa laptop untuk digunakan dalam pelatihan. Acara kegiatan dimulai dengan perkenalan tim abdimas dan dilanjutkan ke materi pelatihan.

Materi pelatihan dimulai dengan perkenalan tentang hot potatoes dan beberapa menu utamanaya. Setelah itu, materi dilanjutkan dengan meng-install program bersamasama yang dipandu oleh tim abdimas. Setelah program selesai di install, peserta mempelajari dan mencoba tentang tata cara membuat soal berbentuk teka-teki silang dengan menggunakan menu Jcross pada program hot potatoes mulai dari menginput kata, clues, pengaturan skor, waktu dan tampilan hingga mensave dalam bentuk HTML.

Tim abdimas juga membuat modul pelatihan hot potatoes yang dibagikan kepada tiap-tiap peserta pelatihan. Modul tersebut berisikan pengenalan hot potatoes versi 6.0.3, tutorial hot potatoes, dan lembar kegiatan. Tutorial hot potatoes berisikan empat hal yang dibahas, antara lain :

1. Pengenalan

2. Instalasi program

3. Pembuatan soal dengan menu yang ada pada program

4. Pengaturan jenis output yang dihasilkan

Dari hasil dokumentasi, diketahui bahwa selama pelatihan peserta terlihat antusias dalam mengikuti kegiatan. Hal ini terlihat dari peserta yang aktif bertanya apabila mengalami kesulitan dalam pengoperasiannya. Selain itu, peserta juga sangat tertarik dengan program tersebut dan ingin mempelajari lebih lanjut tentang program tersebut. 
Setiap peserta menyimpan hasil kegiatan mereka di laptopnya masing-masing, sehingga apabila sewaktu-waktu ingin mempelajari dan mengevaluasi hasil pelatihan dapat digunakan kembali. Pelatihan dilaksanakan secara kondusif dan pada akhir pelaksanaan pelatihan tiap peserta diberikan modul penggunaan hot potatoes.

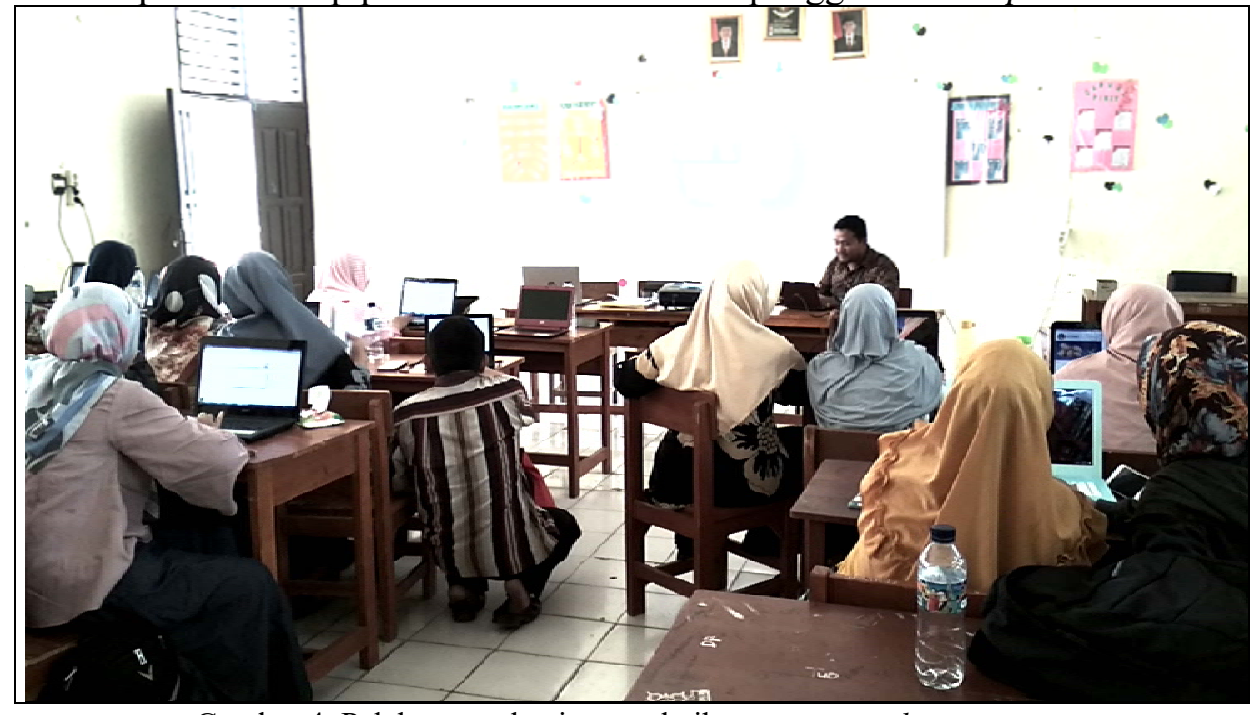

Gambar 4. Pelaksanaan kegiatan pelatihan penerapan hot potatoes.

Tim ABDIMAS memberikan teknis penerapan program.

Rencana kegiatan tahap berikutnya adalah melakukan monitoring lanjutan apabila terdapat kesulitan dari peserta pelatihan guru SDN Sukarapih 01 dan 02 dalam mengoperasikan hot potatoes. Selain itu, pelatihan hot potatoes juga dapat dikembangkan sebagai bahan pelatihan untuk guru-guru dari jenjang sekolah menengah pertama dan menengah atas.

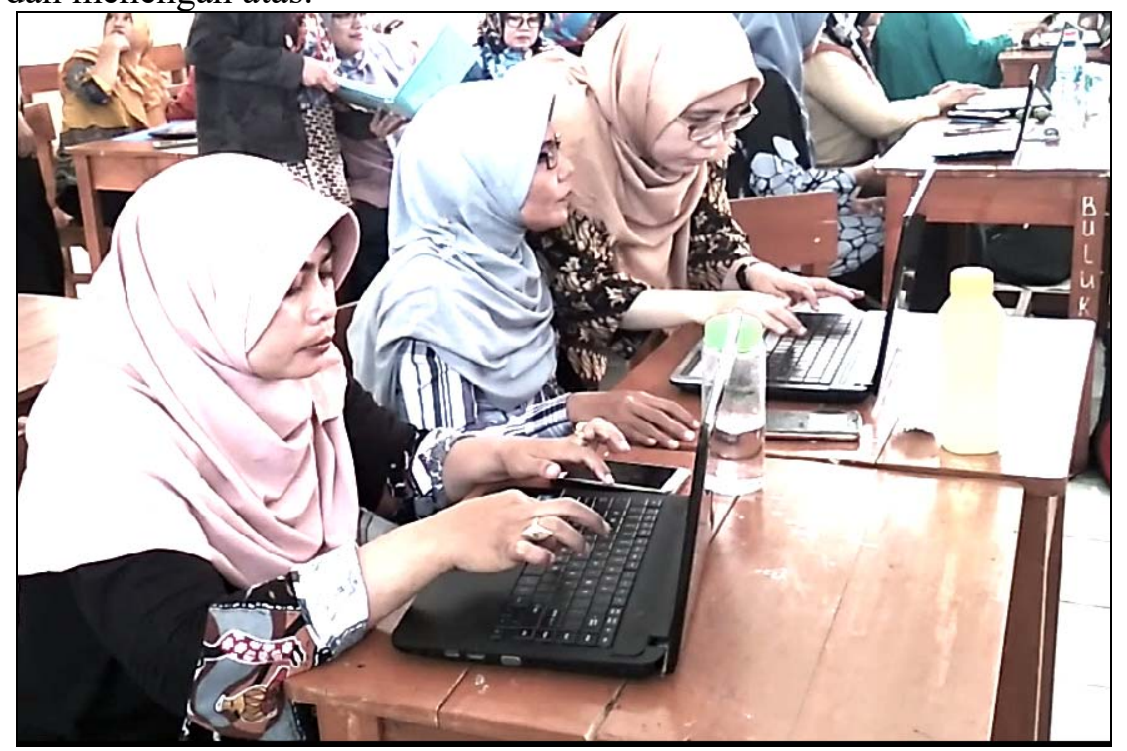

Gambar 5. Pelaksanaan monitoring penerapan hot potatoes.

Tim ABDIMAS membimbing peserta yang menemui kesulitan dalam pengoperasian program.

Sebagian besar peserta mampu menyelesaikan pembuatan instrumen soal yang inovatif dengan aplikasi hot potatoes. Akhir dari pelatihan, peserta membawa modul 
yang berisi materi pelatihan serta hasil pelatihan berupa instrumen soal berupa teka-teki silang yang berisi materi pelajaran yang nantinya dijawab siswa.

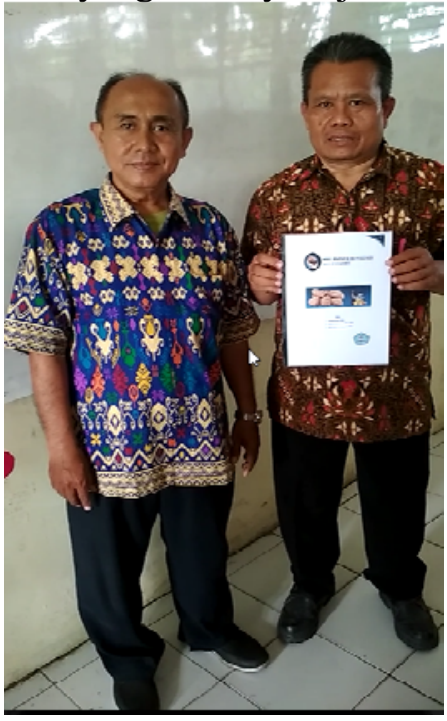

Gambar 6. Penyerahan modul materi pelatihan aplikasi hot potatoes. Tim ABDIMAS menyerahkan modul kepada perwakilan peserta

\section{SIMPULAN}

Program kegiatan pengabdian kepada masyarakat yang bertemakan tentang pelatihan hot potatoes di SDN Sukarapih 01 dan 02 Kabupaten Bekasi telah dilaksanakan dengan baik dan lancar. Para peserta pelatihan sangat antusias mengikuti pelatihan. Hal tersebut dapat dilihat dari keaktifan peserta dalam mengikuti materi pelatihan dan juga keaktifan peserta dalam mengajukan pertanyaan saat mendapatkan masalah atau kesulitan dalam pengoperasian hot potatoes. Rasa ingin tahu dan ingin bisa membuat peserta ingin serius dalam mengikuti pelatihan.

Dari hasil pelatihan, peserta telah mampu membuat aplikasi soal berupa teka-teki silang yang bersifat menarik dan nantinya harus dikerjakan oleh peserta didik atau siswa.

Hampir semua peseta dapat menyelesaikan pembuatan aplikasi hot potatoes sehingga dapat disimpulkan bahwa peserta telah mampu membuat dan menerapkan aplikasi hot potatoes untuk pembuatan instrument soal yang inovatif.

\section{DAFTAR PUSTAKA}

Arsyad, A. (2002). Media Pembelajaran. Jakarta: Rajawali Pers

Henry, S. (2010). Cerdas dengan Game. Jakarta: Gramedia Pustaka Utama.

Ismail, A. (2007). Education Games. Yogyakarta: Pilar Media.

Sudjana, N., \& Rivai, A. (1991). Media pengajaran. Bandung: Sinar Baru Algesindo.

http://thatsmyblue.blogspot.co.id/2015/06/hot-potatoes_24.html (diakses 19 Maret 2018) 